\title{
Organization of management's construction and providing processes in the management system of construction enterprise
}

\author{
Olga Stupakova ${ }^{1, *}$, Vyacheslav Sokolnikov ${ }^{1}$, Irina Osipenkova ${ }^{1}$, and Rosa Nurgalina $^{1}$ \\ ${ }^{1}$ Saint Petersburg State University of Architecture and Civil Engineering, 2-ya Krasnoarmeiskaya st., \\ 4, 190005, St. Petersburg, Russia
}

\begin{abstract}
In this article questions of operational management of construction processes are considered, functions of management system of the construction and providing processes in the construction and Assembly enterprise are given. The article presents the methods of management system organization in CIC and its structure, types, types and forms of management in CIC. In addition, the article presents the main definitions related to management and organization in the CIC. The questions of delayed proactive and delayed lagging control at the stages of project preparation and construction works are considered. Introduced a new concept in the management system of the organization-the tension of operational management of the construction process. It is proved that the management system of the organization using methods of operational adaptive, tracking and optimum planning of performance of construction and providing processes implementing the criterion of the minimum intensity of $T_{o m} \rightarrow 1$ and operating with considerable arrays of the current values of parameters of management represents the perspective direction of introduction of information technologies in activity of the construction enterprises.
\end{abstract}

\section{Operational management}

Operational management (further - OM) of construction and providing processes and their organization are the main contents of the daily activities of workers in the construction and installation company (hereinafter CIC). OM is a leading means of organization, management and regulation of daily production and business activities of CICs, their units. $\mathrm{OM}$ implements functions daily planning, weekly planning, monitoring, forecasting of technological processes in current facilities and resource support for the coming period. Operational management is part of a system [1] control CIC [4].

\footnotetext{
*Corresponding author : olgan_70@mail.ru
} 
Table 1. Objectives of the management system of the NSR.

\begin{tabular}{|c|c|c|}
\hline \multicolumn{3}{|c|}{ USEFUL RESULT OF THE SYSTEM } \\
\hline \multirow{10}{*}{ 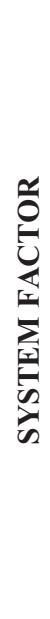 } & Result owned by the enterprise & $\begin{array}{c}\text { Result not belonging to the } \\
\text { enterprise }\end{array}$ \\
\hline & 1. The existing organizational mechanisms & \multirow{6}{*}{$\begin{array}{l}\text { 7. Financial result, which } \\
\text { belongs to the owners of the } \\
\text { enterprise and is outside the } \\
\text { enterprise in various forms of } \\
\text { investment (accounts, } \\
\text { investments, etc.) }\end{array}$} \\
\hline & for regulating the costs of resources & \\
\hline & 2. Availability and use of waste production & \\
\hline & and ma & \\
\hline & $\begin{array}{l}\text { 3. Finding an enterprise in the positive or } \\
\text { negative sector of the conjuncture both of the }\end{array}$ & \\
\hline & $\begin{array}{l}\text { Intormation and material spaces or the } \\
\text { functioning environment }\end{array}$ & \\
\hline & $\begin{array}{l}\text { 4. Availability and condition of the } \\
\text { production and technical base and personnel }\end{array}$ & \multirow{3}{*}{$\begin{array}{l}\text { 8. The objects completed by } \\
\text { construction, which belong to } \\
\text { the owners of the facilities and } \\
\text { are outside the enterprise }\end{array}$} \\
\hline & $\begin{array}{l}\text { 5. The achieved level of quality of } \\
\text { construction and installation works }\end{array}$ & \\
\hline & $\begin{array}{l}\text { 6. The material result of the } \\
\text { implementation of a set of current } \\
\text { technological processes }\end{array}$ & \\
\hline
\end{tabular}

\subsection{Functions of the system of management}

\subsubsection{Functions of the system of management of construction and procurement processes in ClCs:}

1. Logistics

2. Rationing, payment, labour protection

3. Organizational and technical preparation and support of construction

4. Personnel qualification the provision of CIW (construction installation work)

5. Normative-legal support of construction

6. Funding for construction

Management system in CICs is very heterogeneous according to the methods [3] and methods of the organization and its structure can be represented in table 2:

Table 2. Styles, types, forms of governance in the CIC.

\begin{tabular}{|c|c|c|c|}
\hline $\begin{array}{c}\text { Management } \\
\text { type }\end{array}$ & $\begin{array}{c}\text { Kind of } \\
\text { management }\end{array}$ & General contract form & Subcontract form \\
\hline $\begin{array}{c}\text { Deferred } \\
\text { preemptive) }\end{array}$ & Adaptive & $\begin{array}{c}\text { CP at the level of detail the } \\
\text { duration of the erection of } \\
\text { part of the structure as part } \\
\text { of the Project of } \\
\text { organization of } \\
\text { construction }\end{array}$ & $\begin{array}{c}\text { Development of the KP } \\
\text { at the level of detail "the } \\
\text { standard for the } \\
\text { performance of the type } \\
\text { of work as part of the } \\
\text { Project of work } \\
\text { production" }\end{array}$ \\
\hline Deferred (late) & $\begin{array}{c}\text { Tracking } \\
\text { (regulation) }\end{array}$ & $\begin{array}{c}\text { Monitoring compliance } \\
\text { with the requirements of } \\
\text { the CP for the } \\
\text { nomenclature, volumes, } \\
\text { timing and cost of } \\
\text { completed construction } \\
\text { and installation works for } \\
\text { the period }\end{array}$ & $\begin{array}{c}\text { Monitoring the } \\
\text { performance of the } \\
\text { types of work on the } \\
\text { nomenclature, volumes, } \\
\text { timing, cost }\end{array}$ \\
\hline
\end{tabular}




\begin{tabular}{|c|c|c|c|}
\hline \multirow[t]{3}{*}{ Operational } & Adaptive & - & $\begin{array}{l}\text { Determination of the } \\
\text { pace, rhythm and } \\
\text { requirements for } \\
\text { maintaining the } \\
\text { continuity of } \\
\text { technological processes } \\
\text { in the form of weekly } \\
\text { and daily tasks and } \\
\text { schedules. }\end{array}$ \\
\hline & $\begin{array}{c}\text { Tracking } \\
\text { (regulation) }\end{array}$ & $\begin{array}{l}\text { Control: financing of the } \\
\text { Customer, payment for } \\
\text { work performed to } \\
\text { subcontractors, quality of } \\
\text { construction and } \\
\text { installation work }\end{array}$ & $\begin{array}{l}\text { Monitoring of the } \\
\text { financing of the General } \\
\text { Contractor and payment } \\
\text { for work and deliveries. }\end{array}$ \\
\hline & Optimal & $\begin{array}{l}\text { Redistribution of finance } \\
\text { between Participants in } \\
\text { order to maintain } \\
\text { continuity and pace of } \\
\text { construction }\end{array}$ & $\begin{array}{l}\text { Weekly-day planning } \\
\text { for the implementation } \\
\text { of work types and } \\
\text { resource requirements, } \\
\text { the redistribution of } \\
\text { available resources and } \\
\text { the completion of } \\
\text { current processes with } \\
\text { resources in order to } \\
\text { maintain the continuity } \\
\text { and pace of simple } \\
\text { processes }\end{array}$ \\
\hline
\end{tabular}

Every kind and form of management in CIC has their own rules of organization and orders. Based on the above classification, it is advisable to give the basic definitions related to management and organization in CIC.

\section{Basic definition}

1. CONTROL SYSTEM - a set of algorithmic relationships of current values of parameters of construction and providing processes with a terminal $(\mathrm{T})$ and current $(\mathrm{C})$ values of tolerance for all kinds, types and forms of control (the theoretical model).

2. OM OPTIONS - indexes (arrays of data) the status of the current resource's transformation. MAJOR INDEXES of INFORMATION RESOURCE'S TRANSFORMATION: "the declared, the current demand", "confirmed current need", "accessibility", "payment security", "willingness to spend".

3. The CRITERIA of operational planning - "timely readiness of resource are spent in the process".

4. The CRITERIA of operational control - the permissible value of deviations of the parameters of the process: resource supply, the remaining term on schedule, within external and organizational constraints legal, technical nature on the implementation of the process, the current complexity and resource intensity of materials and techniques.

5. ORGANIZATION OF THE OM in CIC - operation of methodological and technical means that implement communication links between performers and algorithmic links of the parameters of the execution of technological and supporting processes [2,4], which establish the pace and rhythm and maintain the continuity of technological processes at the CIC objects (practical OM production model). 


\subsection{Features of operational management}

Some of the types of management (deferred management in the form of calendar planning, economic accounting, etc.) have been studied in sufficient detail. Operational management is studied less than other types of management and is characterized by the following features:

- the ever-changing variety of the current need for technological processes in the resources and stages of meeting this need;

- the constantly changing variety of current organizational, technical and regulatory legal constraints in the implementation of construction and support processes;

- the dispersal of data and performers, the complexity of their communications, the diversity and inconsistency of the criteria of the OM, a severe time deficit in decisionmaking, and low data validity.

The difference between the general contracting and subcontracting forms of management of construction and supporting processes is expressed in the difference in management tasks, conditions and methods of their solution:

- the main task of the CIC in the implementation of the general contract form of management of construction processes at the stage of design and organizational and technical preparation of construction is the more accurate establishment and distribution of the need in resources for long periods (in table 2, delayed proactive management), and at the stage of production of CIW - the implementation of the calendar schedule of subcontractors and their services for the nomenclature, volumes and terms of work and supplies.

- the main task of the CIC in the implementation of the subcontract form of management of construction processes, solved in accordance with the directives of general contractors, is the operational planning and maintenance of the continuity of current technological processes at all CIC facilities.

\subsection{Proactive and late management}

The distinction between the gene and subcontract forms of management of construction and support processes demonstrates the difference in architecture, presentation interface and processing algorithms of the Profit and loss statement. At the same time, in both forms, different types and kinds of planning and management, the processing of resource conversion data takes place, but according to various algorithms, and if we take into account the differences in the organizational principles for building the management system of the CIC, established earlier, then through various communication channels.

Deferred pre-emptive management of the general contract form of process control is performed prior to the start of the construction of the facility. Methods of deferred proactive management: Calendar economic and technological planning for the periods of execution of construction processes, as well as the requirements for labor, material, technical resources and finances for the periods of construction processes.

Delayed management of the general contract form of process control is carried out at the stages of project preparation and construction, with the frequency established by the CP for a particular facility. Delayed management performs a comparison of the planned and current values of the execution of construction and support processes, as well as the expenditure of resources. The general contract form of operational management of construction and support processes at several sites is carried out periodically, according to CP.

The subcontract form of operational management of construction and support processes at several sites is performed daily. The tasks of the OM are the establishment of the current 
need for simple construction processes in resources (follow-up management), maintenance of continuity building processes (adaptive control) and building processes (optimal) management.

Follow-up control (regulation) - minimizes the difference between the current and planned values of process execution parameters, and is carried out through negative feedback circuits (FC) of the control scheme.

Adaptive management performs a permissible adjustment - the current planned values for the execution of processes and their resource support.

Optimal management performs the completion of resources by the current needs of processes according to the current criteria of optimality.

Adaptive and optimal controls are carried out by circuits of positive control circuit FC.

\section{The tension of the operational management}

The tension of the operational management of each construction process $-\boldsymbol{T}_{\text {om_process }}$ was defined in [6] as "a measure of compliance: the actual provision of resources for the construction process - the planned needs and the weekly-daily work schedule - to the calendar plan in the current outside and in-site limitations of the process". On the other hand, the intensity of operational management of construction processes and their resource support can also be interpreted as "a measure of the effectiveness of both organization and operational management at the current time". As a differential characteristic of the quality function of management and organization in the sense that "the higher the tension, the lower the level of both the organizational basis of management and the methods and methods of management. In addition to the organizational and managerial institutions in the enterprise that are integral permanent - active averaged characteristics of the effectiveness of organization and management.

In [5], with respect to building processes, it was shown that, in general, $\mathrm{H}$ depends on the following factors: $\boldsymbol{\delta}_{V \text { stat }}$ is the indicator of the declared current resource demand; $\boldsymbol{\delta}_{\boldsymbol{c o n} \boldsymbol{v}}-$ the indicator of the claimed demand; $\boldsymbol{\delta}_{\boldsymbol{V}} \boldsymbol{T}$ - indicator of the timeliness of the installationlaying process; $\boldsymbol{\delta}_{\text {lim }}$ is an indicator of off-site and on-site current organizational, technical and legal constraints on the implementation of the technological process or the transformation of the state of resources.

$$
\begin{gathered}
T_{\text {om_process }}=f\left(\delta_{\text {lim }}, \delta_{V \text { stat }}, \delta_{\text {conv }}, \delta_{V T}\right) \\
T_{\text {om_process }}=\delta_{1 \mathrm{lim}} *\left(\sum_{i=1}^{n} \frac{\delta_{(V S T A T) i} \times \delta_{(V T) i}}{\delta_{(C O N V) i}}\right)
\end{gathered}
$$

where: $\mathrm{n}$ - the number of resources of the current process demand.

The organization management system that uses the methods of operational adaptive, follow-up and optimal planning for the implementation of construction and support processes, realizing the criterion of minimum tension $T_{o m} \rightarrow 1$ and operating with significant arrays of current values of control parameters, represents a promising direction for the introduction of information technologies in the activities of construction enterprises.

\section{References}

1. P.K. Anohin, Principal questions of the general theory of functional systems (DirectMedia, Moscow, 2008)

2. N. Viner, Cybernetics (Sovetskoe radio, Moscow, 1968) 
3. O. Lange, Introduction to Economic Cybernetics (Progress, Moscow, 1968)

4. T. Saati, K. Kerns, Analytical planning. Organization of systems (Radio and communication, Moscow, 1991)

5. V.V. Sokolnikov, The improvement of operational planning of construction work and resource support based on a unified information management environment, Dissertation for the degree of candidate of technical sciences (2017) 